\title{
Persepsi Pelanggan Daya 900 AA Atas Penyesuaian Subsidi Bertahap dan Penerapan Tarif Ganda
}

\author{
Adityo Reinaldi ${ }^{1}$ dan Nico Wattimena ${ }^{2}$ \\ ${ }^{1,2}$ Institut Komunikasi dan Bisnis LSPR, Jakarta, Indonesia
}

\begin{abstract}
ABSTRAK
Kebijakan yang ditetapkan oleh Pemerintah Republik Indonesia untuk tarif yang berlaku bagi pelanggan PLN daya 900 VA golongan rumah tangga telah menimbulkan banyak gejolak. Pada kelompok tarif tersebut dilakukan penyesuaian subsidi secara bertahap dan penerapan tarif ganda. Di lapangan muncul banyak kendala dan perbedaan pandangan oleh banyak pihak. Kegiatan sosialisasi atas pemberlakuan aturan baru telah sering dilakukan, namun demikian masih banyak pihak merasa kebingungan atas penerapan aturan tersebut. Dengan menggunakan metode kualitatif, penelitian dilakukan dengan metode wawancara semi struktural ke 6 (enam) pelanggan daya 900 VA. Dari hasil penelitian diperoleh bahwa serangkaian proses persepsi berlangsung di benak para konsumen PLN atas penerapan aturan penyesuaian subsidi bertahap dan penerapan tarif ganda. Terdapat usaha aktif dari sebagian besar narasumber untuk mencari informasi lebih lanjut mengenai aturan yang diterapkan pada sambungan listrik daya 900 VA di rumah masing-masing. Konsumen sebagai pengguna akhir produk listrik dan juga objek peraturan telah memiliki persepsi yang beragam.
\end{abstract}

Kata kunci: Persepsi; aturan; tarif

\begin{abstract}
The policy set by the Government of the Republic of Indonesia for the applicable tariff for household customers with 900 VA power has caused a lot of turmoil. In this tariff group, the subsidy adjustments are carried out gradually and the application of multiple tariffs. In the field, there were many obstacles and different views by many parties. Socialization activities on the implementation of new regulations have been carried out frequently, however, many parties still feel confused about the application of these regulations. Using a qualitative method, the study was conducted by using the semi-structural interview method to 6 (six) 900 VA customers. From the research results, it was found that a series of perceptual processes took place in the minds of PLN consumers on the application of the gradual subsidy adjustment rules and the application of multiple tariffs. There is an active effort from most of the interviewees to find more information about the rules that apply to the $900 \mathrm{VA}$ power line in their respective homes. Consumers as end users of electrical products and also objects of regulation have various perceptions.
\end{abstract}

Keywords: Perceptions; rules; rates 


\section{PENDAHULUAN}

Di tahun 2017 pemerintah Indonesia memperkenalkan kebijakan penyesuaian Tarif Tenaga Listrik yang diberlakukan di PT PLN (Persero) dengan strategi yang berbeda dari sebelumnya dimana hanya menimbulkan perubahan tarif bagi pelanggan PLN daya 900 VA (Volt Ampere) yang diperuntukan khusus untuk rumah tangga. Tarif tersebut dibagi dalam dua kelompok tarif, yakni R1-900 dengan tarif tetap sama sebagaimana sebelumya dan R1-900M atau kelompok mampu sehingga terkena perubahan tarif secara bertahap. Per Oktober 2016 jumlah pelanggan daya 900 VA berjumlah 23.044.534 unit dimana yang terkena imbas perubahan menjadi tarif R1-900M adalah 80\% dari total tersebut. Sedangkan sisanya sekitar 3.928 .632 unit yang tergolongan Rumah Tangga Miskin dan Tidak Mampu (RTMTM) sehingga mendapatkan tarif listrik tetap R1900.

Pemerintah sebagaimana tertuang dalam buku Petunjuk Teknis Pelaksanaan Subsidi Tepat Sasaran (2016) menjelaskan bahwa untuk lebih menghemat anggaran subsidi listrik, pemerintah menerapkan Kebijakan Subsidi Listrik Tepat Sasaran dengan menetapkan sasaran pemberian subsidi listrik khusus bagi kelompok Rumah Tangga Miskin dan Tidak Mampu (RTMTM). Perubahan tarif yang berarti kenaikan harga selalu memicu reaksi konsumen sebagaimana telah terjadi banyak aksi massa menolak keputusan kenaikan tersebut di berbagai wilayah di Indonesia.

Atas penerapan strategi ini pemerintah juga membuka Posko Pusat Penanganan Pengaduan bagi warga yang merasa tarif yang diterapkan tidak sesuai kondisi ekonomi. Tata cara pelaporan pengaduan dan pengelolaannya telah ditetapkan melalui Peraturan Menteri ESDM nomor 29 tahun 2016 tentang Mekanisme Pemberian Subsidi Tarif Tenaga Listrik untuk Rumah Tangga.

PLN dan Pemerintah telah melakukan berbagai upaya sosialisasi ke masyarakat. Nama resmi program tersebut adalah Subsidi Listrik Tepat Sasaran. Beragam tema pesan telah disampaikan dengan fokusisi pesannya masing-masing. Sosialisasi ke masyarakat umum dilakukan melalui iklan televisi, situs web, iklan koran, poster, pertemuan langsung sosialisasi di masyarakat, dan melalui media sosial. Namun demikian masih banyak pihak yang menilai bahwa sosialisasi yang telah dilakukan masih kurang sehingga masyarakat merasa tidak mendapatkan informasi yang tepat dan cukup. Banyak pihak telah mengkritisi pemberlakukan aturan tersebut. Oleh karena itu peneliti bermaksud untuk memahami langsung persepsi yang muncul di pelanggan atas kebijakan baru ini. Berdasarkan penjabaran yang disampaikan pada latar belakang di atas maka didapatkan rumusan masalah atas penelitian ini, yakni "bagaimana persepsi yang muncul di pelanggan PLN daya 900 VA atas penerapan aturan penyesuaian subsidi bertahap dan penerapan tarif ganda?". Adapun tujuan penelitian yaitu untuk memahami persepsi yang muncul dari pelanggan masyarakat atas penerapan strategi penyesuaian subsidi bertahap dan penerapan tarif ganda dan mengetahui sumber yang menjadi dasar munculnya persepsi pelanggan PLN daya 900 VA atas penerapan strategi penyesuaian subsidi bertahap dan penerapan tarif ganda 


\section{Teori Uses and Gratification}

Dalam proses usaha masyarakat untuk mendapatkan informasi, maka salah satu teori yang dapat digunakan dalam penelitian ini adalah Uses and Gratification. Teori ini merujuk pada usaha-usaha aktif dari para individu dalam memenuhi kebutuhannya akan informasi yang diinginkan. Teori Penggunaan dan Pemenuhan Kebutuhan (Uses and Gratification) merupakan salah satu teori komunikasi massa dimana salah satu fokusnya adalah pada khalayak sebagai penentu pemilihan pesan dan media. Masyarakat aktif berusaha mencari informasi dengan memilih media yang dianggap tepat untuk membuat mereka merasa puas. Menurut Hidayat (2007) kita bisa memahami interaksi orang dengan media melalui pemanfaatan media oleh orang itu (uses) dan kepuasan yang diperoleh (gratification).

\section{Persepsi}

Persepsi merupakan inti dari serangkaian proses dalam komunikasi. Sehingga salah satu kunci kesuksesan kita dalam berkomunikasi ditentukan oleh hasil persepsi yang terbentuk di benak para penerima pesan, apakah persepsi yang muncul tersebut sesuai dengan tujuan yang diharapkan oleh pemberi pesan. Dijelaskan oleh Kotler \& Keller (2002) bahwa persepsi merupakan proses dimana seorang individu memilih, mengelompokkan, dan menginterpretasikan masukan-masukan informasi untuk menciptakan gambaran yang berarti atas duniawi.

Setiap orang bisa memiliki persepsi yang berbeda pada hal atau fokus yang sama. Hal tersebut terjadi dikarenakan oleh tiga proses perceptual (perceptual process) dari Kotler dan Keller (2002:95) yakni perhatian selektif, distorsi selektif, dan retensi selektif. Perhatian selektif (selective attention) berarti setiap orang memperoleh begitu banyak stimuli dimana sebagian besar stimuli tersebut akan disaring untuk diseleksi. Penerima pesan akan mensortir sebagian besar rangsangan yang diterima oleh inderanya. Distorsi selektif (selective distortion) menunjukkan kecenderungan untuk mengaitkan informasi dengan pemahaman pribadi dan mengartikan informasi yang berkaitan dengan pradugaan oleh penerima pesan. Penerima rangsangan akan mendistorsi informasi agar sesuai dengan keyakinan dan harapan yang telah dimilikinya sebelumnya. Retensi selektif (selective retention) yaitu proses untuk mengingat informasi yang berkaitan dengan apa yang individu senangi dan melupakan hal yang tidak individu sukai. Hal ini karena penerima informasi tidak bisa mengingat begitu banyak informasi yang disampaikan kepadanya, melainkan lebih mempertahankan informasi yang mendukung sikap dan keyakinannya. Proses terbentuknya persepsi di dalam benak setiap individu telah dijabarkan oleh Schiffman dan Kanuk (2007) dalam 3 (tiga) aspek pembentukan persepsi yakni meliputi pemilihan persepsi, pengorganisasian persepsi, dan interpretasi persepsi. Perceptual selection (pemilihan persepsi) menunjukkan terdapat begitu banyak stimuli yang diterima indra kita setiap harinya. Kita akan memilih dan menyeleksi dari sekian banyak stimuli yang hadir ke indra kita. Ada dua faktor yang berpengaruh besar terhadap stimuli apa yang akan dipilih yakni pengalaman sebelumnya yang mempengaruhi harapan (yang telah disiapkan atau diatur untuk dicari) dan motif (kebutuhan, selera, ketertarikan, dan sebagainya).

Kemudian perceptual organization (pengorganisasian persepsi) mengindikasikan proses 
mengelompokkan stimuli-stimuli yang terpisah-pisah dan berlainan dimana sebelumnya telah dipilih kedalam kelompok-kelompok dan merasakan semua itu sebagai kesatuan utuh. Tiga prinsip dasar perceptual organization yaitu figure and ground: dari stimulus yang diterima selanjutnya dipilih mana yang akan dijadikan fokus atau bentuk utama (figure) dan mana yang menjadi latar (ground), grouping atau pengelompokan stimuli, dan closure yakni penyelesaian atas proses sebelumnya.

Selanjutnya Perceptual Interpretation (Interpretasi persepsi) adalah proses seseorang mengartikan stimuli yang telah dipilih dan diorganisasikan sebelumnya. Mulyana (2012) menyatakan bahwa proses penafsiran (interpretation) merupakan inti dari persepsi, yang identik dengan penyandian balik (decoding) dalam proses komunikasi. Pengalaman sebelumnya dan interaksi sosial membantu membentuk harapan tertentu yang menyediakan kategori yang digunakan seorang dalam mengintepretasikan stimuli. Manusia tidak dapat menginterpretasikan makna setiap objek secara langsung, melainkan menginterpretasikan makna informasi yang kita percayai mewakili objek tersebut. Seberapa dekat hasil interpretasi seseorang dengan kenyataan yang sebenarnya tergantung pada kejelasan stimulus yang diterima, pengalaman sebelumnya dari pemersepsi, motif dan kepentingannya saat melakukan persepsi

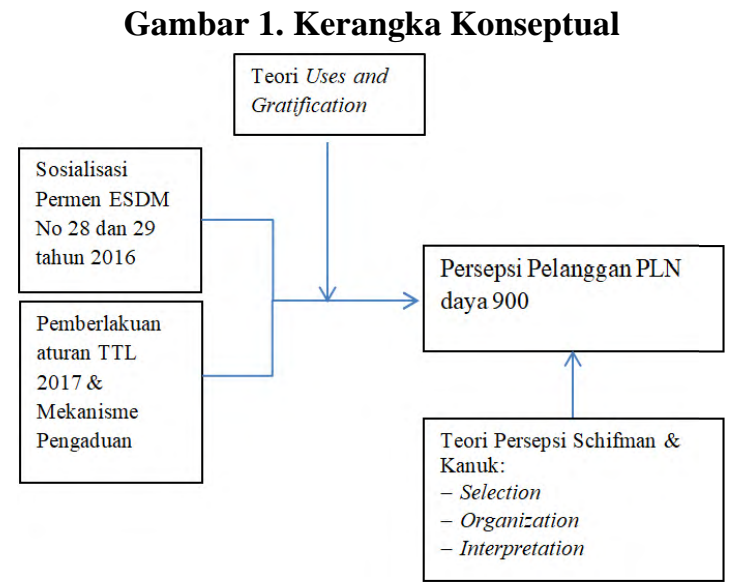

Sumber: Adaptasi dari Schifman \& Kanuk (2007)

Penelitian ini ingin mengetahui bagaimana persepsi pelanggan daya $900 \mathrm{VA}$ atas diberlakukannya penyesuaian subsidi listrik oleh pemerintah secara bertahap disamping itu pula penerapan tarif ganda, dengan menggunakan teori pembentukan persepsi dari Schiffman dan Kanuk (2007). Usaha-usaha sosialisasi dan penyebaran informasi telah dilakukan oleh pemerintah dan PLN melalui berbagai media. Pada jadwal yang telah ditentukan (01 Januari 2017) maka peraturan tarif baru telah dilaksanakan dan dilanjut pula oleh proses pengaduan bagi yang merasa masih perlu disubsidi. Atas pemberlakukan aturan dan kegiatan sosialisasi kepada masyarakat yang telah dilakukan tersebut peneliti juga ingin meneliti dari sudut pandang teori uses and gratification. 


\section{METODE PENELITIAN}

Penelitian ini menggunakan metode kualitatif dengan perspektif fenomenologi yang dilakukan dengan studi lapangan. Sedangkan paradigma yang menjadi dasar dalam penelitian ini adalah post positivism. Mulyana dan Solatun (2008:5) menjelaskan bahwa penelitian kualitatif adalah penelitian yang bersifat interpretif (menggunakan penafsiran) yang melibatkan banyak metode dalam menelaah masalah penelitiannya.

Data yang dikumpulkan dalam penelitian ini meliputi Data Primer dan Data Sekunder. Data primer diperoleh dari proses observasi di lapangan yang kemudian dilanjut pada proses wawancara ke para narasumber. Data sekunder diperoleh melalui studi dokumen dan literatur yang berhubungan dengan fenomena yang diteliti. Yang menjadi narasumber dalam penelitian ini adalah 6 pelanggan PLN daya 900 VA, telah menjadi pelanggan PLN, dan berusia di atas 20 tahun. Para Narasumber terdiri dari komposisi pelanggan yang masih menerima subsidi (R1-900), dan pelanggan yang tidak menerima subsidi (R1M-900). Daftar narasumber adalah Anita (546103163480), Esti Purwanti (546105815398), Gimo (546106182621), Amran (566100283919 a/n H. Sayuti), Komariyah (14031579072 a/n Cadim), Neneng (546104116677 a/n SALEH).

Penelitian ini fokus pada proses persepsi dari para narasumber. Menurut Schiffman dan Kanuk (2007) terdapat tiga aspek yang mempengaruhi persepsi, yakni Selection, Organization, Interpretation. Dari ketiga aspek tersebut selanjutnya dikembangkan menjadi pertanyaan wawancara. Penelitan yang telah dilakukan menggunakan teknik analisis yang dikemukakan oleh Miles \& Huberman (1992) meliputi: Reduksi Data (Data Reduction), Penyajian Data (Data Display), Penarikan serta Pengujian Kesimpulan (Drawing and Verifying Conclusions). Penelitian ini memakan waktu selama 3 bulan yakni dari bulan November 2017 hingga Februari 2018. Lokasi dilakukannya penelitian tersebar di beberapa tempat seputar Kota Tangerang.

\section{HASIL DAN PEMBAHASAN}

PT Perusahaan Listrik Negara (Persero) adalah perusahaan penyedia jasa ketenagalistrikan bagi masyarakat umum di Indonesia yang merupakan entitas badan usaha milik negara. Proses bisnis perusahaan ini mencakup dari hulu hingga hilir, yakni mulai dari produksi tenaga listrik hingga penyaluran energi dan pelayanan jasanya pada konsumen akhir.

Sejak 1994, status PLN ditetapkan menjadi Perusahaan Perseroan yang merupakan Badan Usaha Milik Negara. Selain itu sejak tahun 1972 PLN merupakan Pemegang Kuasa Usaha Ketenagalistrikan (PKUK) dengan tugas menyediakan tenaga listrik bagi kepentingan umum. Oleh karena itu dalam menjalankan usaha bisnisnya, tarif atas produk PLN ditentukan oleh pemerintah melalui Peraturan Menteri Energi Sumber Daya Mineral. Sebagian besar produk ketenagalistrikan di Indonesia memang disediakan oleh PLN. Namun demikian Undang Undang nomor 30 tahun 2009 tentang Ketenagalistrikan menjadi dasar regulasi bahwa pihak lain juga memiliki kewenangan juga dalam penyediaan energi listrik. 


\section{Program Subsidi Tepat Sasaran}

Berdasarkan UU nomor 30 tahun 2009 tentang Ketenagalistrikan maka tarif tenaga listrik yang harus dibayar oleh para konsumen PLN ditetapkan oleh Pemerintah RI. Tarif terbaru yang berlaku saat ini adalah berdasarkan Peraturan Menteri ESDM nomor 28 tahun 2016 tentang Tarif Tenaga Listrik yang Disediakan oleh PT PLN (Persero). Tarif tersebut mulai diberlakukan sejak 01Januari 2017. Melengkapi aturan tersebut, juga telah ditetapkan dan diberlakukan Peraturan Menteri ESDM nomor 29 tahun 2016 tentang Mekanisme Pemberian Subsidi Tarif Tenaga Listrik untuk Rumah Tangga.

Secara umum tarif yang ditetapkan dalam Peraturan Menteri ESDM nomor 28 tahun 2016 tersebut memiliki kesamaan dengan tarif yang telah berlaku sebelumnya. Pada dasarnya peraturan tersebut hanya merupakan perbedaan tarif pada pelanggan rumah tangga daya 900 VA yang kini dibagi menjadi pelanggan R1-900 dan R1-900M (Rumah Tangga Mampu). Adapun perbandingan besaran tarif yang diperkenalkan pada penerapan Peraturan Menteri terbaru untuk pelanggan rumah tangga daya $900 \mathrm{VA}$ adalah sebagai berikut:

Kegiatan sosialisasi atas penerapan tarif berdasarkan Peraturan Menteri ESDM nomor 28 tahun 2016 telah banyak dilakukan, baik oleh Pemerintah maupun PLN di berbagai media seperti poster, iklan televisi, iklan radio, dan internet. Dari sisi pemerintah sendiri mencakup lintas sektor dan bidang yang terlibat yakni meliputi Kementrian Dalam Negeri (termasuk juga seluruh pemerintah daerah), Kementrian ESDM, Kementrian Sosial, dan Tim Nasional Percepatan Penanggulangan Kemiskinan (TNP2K). Inti dari tema sosialisasi yang digunakan disebut sebagai program Subsidi Tepat Sasaran. Baik PLN maupun Pemerintah memiliki porsi dan peran serta dan pesan masing-masing dalam rangka melakukan sosialisasi kepada masyarakat.

Selain proses sosialisasi peraturan, baik dari sisi pemerintah dan PLN, telah memiliki tugas masing-masing untuk menindaklanjuti laporan pengaduan pelanggan agar bisa mendapatkan subsidi (menjadi tarif R1-900) maupun melepaskan subsidi yang mereka terima (menjadi tarif R1-900M). Pengelolaan pengaduan pelanggan atas tarif terbaru ini menggunakan dasar Peraturan Menteri ESDM nomor 29 tahun 2016 tentang Mekanisme Pemberian Subsidi Tarif Tenaga Listrik untuk Rumah Tangga.

\section{Analisis Persepsi Pelanggan}

Hasil wawancara peneliti dengan para narasumber penelitian yang disajikan dalam bentuk analisis berdasarkan 3 tahapan terbentuknya Persepsi berdasarkan Schiffman dan Kanuk (2007).

\section{Selection}

Pada tahap pertama dalam proses memilih atau menyeleksi beragam rangsangan atau stimulistimuli yang pelanggan terima. Dengan indikator sebagai berikut"Apakah anda mengetahui tentang aturan penyesuaian subsidi bertahap dan penerapan tarif ganda daya 900 VA?”. Berdasarkan jawaban yang didapat secara keseluruhan narasumber mengetahui mengenai kenaikan tarif karena merasakan pada tagihan rekening yang cenderung naik dan nilai token 
listrik prabayar yang menjadi lebih kecil nilai $\mathrm{kWh}$ yang diperoleh. Namun demikian masih belum semua narasumber yang memahami lebih rinci mengenai aturan tersebut. Hal yang paling berpengaruh terhadap konsumen adalah mengenai total tagihan yang dirasakan terus naik dan nilai token $\mathrm{kWh}$ yang mengecil. Dari kesadaran akan nilai tarif yang semakin tinggi ini konsumen berusaha mencari tahu informasi lebih lanjut berkaitan dengan kenaikan tarif listrik tersebut.

Narasumber 1 merasa berhak mendapatkan tarif bersubsidi (R1-900) namun demikian mendapatkan informasi bahwa hak datanya digunakan untuk nomor pelanggan lain. Hal ini juga sama dengan Narasumber 4 yang data haknya (Basis Data Terpadu) untuk disubsidi digunakan oleh pelanggan lain yakni tetangganya dan ini sebagai akibat dari proses survei oleh petugas yang lalai dan salah nomor meter $\mathrm{kWh}$ milik tetangganya yang terletak bersebelahan dengan meter kWh miliknya.

Jawaban Narasumber 6 di awal menyatakan lugas tidak tahu mengenai kebijakan kenaikan tarif bertahap dan penerapan tarif ganda, namun demikian setelah disimak lebih lanjut narasumber menyadari dari tagihan listrik yang terus naik.

Indikator kedua dalam tahap Selection ini adalah "Hal-hal apa saja yang anda ketahui mengenai tarif listrik daya 900 VA terbaru?". Dari jawaban 6 narasumber tersebut diketahui 5 narasumber mengetahui cukup banyak mengenai kebijakan dan aturan terbaru ini,. Hanya Narasumber 3 saja yang mengatakan tidak terlalu mempermasalahkan. Hal ini karena Narasumber 3 merasa menerima jika tarif telah dinaikkan dan meskipun dirinya tidak termasuk dalam tarif bersubsidi (R1-900).

Narasumber 4 dan 5 adalah pelanggan dengan posisi rumah berdekatan yang pada awalnya sama-sama termasuk tarif R1-900M, namun kemudian dari informasi pelanggan bahwa telah dilakukan survei dari PLN di Maret 2107 untuk pendataan Rumah Tangga Miskin yang berhak mendapatkan subsidi. Diinformasikan bahwa hasil dari proses survei dari PLN tersebut menyatakan kedua narasumber berhak mendapatkan subsidi (bisa masuk R1-900). Pada akhirnya, pada Narasumber 5 diterapkan tarif R1-900 di pertengahan tahun 2107. Narasumber 5 juga menyadari bahwa telah diterapkan tarif ganda di daya 900VA karena di rumah terdapat 2 sambungan listrik dengan tarif yang berbeda pada daya yang sama.

Indikator ketiga dalam tahap Selection ini adalah "Bagaimana cara anda mengetahui aturan penyesuaian subsidi bertahap dan penerapan tarif ganda daya 900 VA?" Dari jawaban para narasumber atas pertanyaan ketiga ini menunjukkan ada usaha mencari informasi lebih lanjut atas peraturan tarif di daya 900 VA terlihat di Narasumber 1, 2, 4, dan 6. Para narasumber telah mencari informasi hingga ke kantor Desa, kantor Kecamatan, dan PLN unit setempat. Para narasumber tersebut selain berusaha mencari informasi juga telah melakukan serangkaian proses permohonan pengaduan untuk beralih dari tarif R1-900M ke R1-900 yang dimulai dari kantor Kelurahan. Para narasumber menceritakan detail usahanya untuk beralih dari R1-900M menjadi R1-900. 


\section{Organization}

Pada tahap kedua dari proses persepsi informasi yang diterima akan dikelompokkan atau diorganisasikan. Indikator pertama dalam tahap Organization ini adalah "Apa yang menjadi kelebihan program ini bagi Anda?”. Secara keseluruhan jawaban para narasumber ketika dimintai pendapat mengenai mengenai kelebihan program penerapan tarif ganda dan subsidi bertahap di daya 900 VA masih mengacu manfaat (benefit) langsung apa yang diterima oleh masing-masing narasumber saat itu. Narasumber 1, 2, 3, 4, dan 6 yang diterapkan tarif R1900M pada langganan sambungan listriknya cenderung menjawab dengan hal yang berkaitan dengan kenaikan tarif. Malah tidak sedikit para narasumber cenderung sulit memberikan jawaban mengenai kelebihan program ini dari aturan yang telah dijalankan.

Indikator kedua dalam tahap Organization ini adalah “Apa yang menjadi kekurangan program ini bagi Anda?". Fokus jawaban dari Narasumber 1, 3, dan 6 memiliki kesaman yakni pada tarif yang lebih mahal dari sebelumnya sehingga berimbas pada biaya listrik yang lebih tinggi. Narasumber 2 memberi kesimpulan bahwa program dirasakan tidak tepat sasaran, karena narasumber merasa jika dibandingkan dengan kondisi ekonominya seharusnya mendapatkan tarif R1-900 dengan tarif yang lebih rendah. Secara umum para Narasumber lebih lugas dalam menyebutkan kekurangan yang ada dalam aturan tersebut. Narasumber lebih fokus pada kelemahan dari aturan dibandingkan kelebihannya.

\section{Interpretation}

Pada tahap ketiga dari proses persepsi informasi yang diterima akan diinterpretasikan atau diartikan berdasarkan stimuli yang telah dipilih dan diorganisasikan di setiap individu. Indikator pertama dalam tahap Interpretation ini adalah "Apakah menurut anda pemerintah dan PLN telah cukup menginformasikan aturan penyesuaian subsidi bertahap dan penerapan tarif ganda daya 900 VA?". Narasumber 2, 4, 5, dan 6 memiliki kesamaan jawaban yakni merasa pemerintah dan PLN kurang cukup dalam usaha menginformasikan aturan penyesuaian subsidi bertahap dan penerapan tarif ganda daya 900 VA. Para narasumber telah berusaha untuk mencari informasi kepada pihak yang terkait seperti kantor PLN unit, RT/RW, kantor Kelurahan, dan kantor Kecamatan. Namun demikian banyak kondisi ditemui para narasumber bahwa petugas di Kelurahan atau Kecamatan tidak memberikan informasi yang cukup dan bahkan tidak menyediakan formulir pengaduan yang seharusnya disediakan.

Indikator kedua dalam tahap Interpretation ini adalah "Bagaimana menurut anda penerapan aturan penyesuaian subsidi bertahap dan penerapan tarif ganda daya 900 VA?'. Narasumber 1, 4, dan 5 memberikan tanggapan positif pada penerapan aturan penyesuaian subsidi bertahap dan penerapan tarif ganda daya 900 VA. Meskipun menyatakan program bagus, namun demikian Narasumber 4 memberikan catatan khusus berkaitan dengan permasalahan yang dialami, dimana narasumber mengulang kembali mengeluh yang telah disampaikan pada pertanyaan sebelumnya.

Indikator ketiga dalam tahap Interpretation ini adalah "Apakah tarif listrik yang diterapkan pada rumah anda sudah sesuai?". Narasumber 1 tidak menyatakan langsung keberatan atas penerapan tarif listrik yang diberlakukan pada sambungan di rumahnya. Namun demikian, 
Narasumber masih memiliki harapan untuk bisa mendapat tarif yang lebih rendah. Harapan akan penerapan tarif yang lebih murah juga disampaikan oleh Narasumber 2 namun tidak lugas menyatakan apakah kesesuaian tarif yang dikenakan. Hanya Narasumber 5 yang memberikan jawaban secara lugas mengenai kesesuaian tarif yang diberlakukan. Hal ini karena narasumber telah mendapatkan tarif R1-900 untuk sambungan listriknya.

Indikator keempat dalam tahap Interpretation ini adalah "Apakah ada usaha tindak lanjut dari anda setelah mengetahui beragam informasi mengenai perubahan tarif?”. Sebagaimana yang telah diungkapkan dalam jawaban pada pertanyaan sebelumnya bahwa Narasumber 1, 2, 4, dan 6 telah melakukan usaha pengaduan untuk melakukan permohonan perubahan tarif dari R1900M menjadi R1-900 untuk tarif yang lebih rendah. Hingga saat ini kesemua narasumber yang telah mengadu tersebut belum mendapatkan perubahan tarif sehingga masih membayar dengan tarif yang lebih tinggi. Bahkan Narasumber 4 menyatakan kembali kekecewaannya dan merasa telah melakukan cukup usaha mengadu sesuai prosedur dan memang secara data dinyatakan berhak mendapatkan Tarif R1-900 namun demikian basis datanya digunakan untuk meter tetangganya sebagai dampak dari kesalahan pencatatan oleh pihak pengsurvei.

\section{Analisis Data}

Dalam tahap analisis data penelitian ini menggunakan teknik dari Miles dan Huberman (1984) sebagaimana dijelaskan oleh Moleong (2016) melalui 3 tahapan persepsi dari Schifman dan Kanuk yang meliputi perceptual selection, perceptual organization, dan perceptual interpretation. Disamping itu pula proses analisis data juga mempertimbangkan saat individu (narasumber penelitian) menerima rangsangan atau stimuli dengan membandingkan pada teori Uses and Gratification.

Penelitian yang dilakukan dengan proses wawancara secara terstruktur terhadap 6 pelanggan PLN keperluan rumah tangga daya 900 VA. Dari beragam jawaban narasumber yang telah disampaikan diperoleh dari berbagai sudut pandang, fokus permasalahan, dan pemahaman yang berbeda.

Berkaitan dengan adanya penerapan aturan penyesuaian subsidi bertahap dan penerapan tarif ganda daya $900 \mathrm{VA}$, narasumber telah menerima banyak stimuli atau rangsangan yang membuat mereka mulai sadar akan adanya penerapan aturan tersebut. Kesadaran narasumber atas banyaknya stimuli dilanjutkan dengan usaha-usaha untuk mendapatkan informasi lebih mendalam mengenai aturan yang diberlakukan. Usaha-usaha dari penerima informasi atau pesan untuk berperan aktif memilih media guna pemenuhan kepuasan (gratification) mereka. Hal ini sesuai dengan Teori uses and gratification yang dikemukakan oleh Blumler, Gurevitch dan Katz (Griffin, 2003) menyatakan bahwa pengguna media memainkan peran yang aktif dalam memilih dan menggunakan media.

Para narasumber secara keseluruhan mengetahui adanya aturan kenaikan tarif bertahap dan kebijakan pemberlakuan tarif ganda pada daya 900 VA. Namun demikian tidak semua memahami dengan rinci aturan yang diberlakukan. Para narasumber memberikan perhatian lebih pada hal-hal atas aturan yang berkaitan dengan pemenuhan kebutuhan mereka yakni 
ketersediaan energi listrik dan biaya yang harus dikeluarkan. Hal ini berkaitan dengan proses Perceptual Selection dimana narasumber menerima begitu banyak stimuli atau rangsangan ke indra mereka maka individu berusaha melakukan pemilahan dan pemilihan rangsangan apa saja yang menjadi perhatian narasumber. Menurut Schiffman dan Kanuk (2007) menjelaskan bahwa stimuli mana saja yang akan dipilih konsumen tergantung pada: (1) pengalaman yang dimiliki sebelumya yang kaitan pada harapan mereka, (2) motivasi mereka saat waktu itu (kebutuhan, hasrat, ketertarikan, dan sebagainya).

Para narasumber memang tidak memahami secara utuh aturan yang diberlakukan. Bahkan terdapat beberapa pemahaman narasumber yang berbeda dengan aturan yang diberlakukan. Namun demikian, terdapat usaha aktif dari para narasumber untuk memperoleh informasi lebih lanjut yang dibutuhkan. Narasumber menceritakan berbagai usaha mereka untuk dengan sengaja mencari tahu informasi dari beragam media yang ada.

Secara umum, narasumber memberikan perhatian pada kenaikan biaya rekening listrik atau nilai token yang mereka bayar. Sebagian besar stimuli yang diterima memunculkan kesadaran pelanggan untuk mengetahui lebih mendalam mengenai aturan yang berlaku. Sebagaimana telah diberitahukan sebelumnya bahwa 4 narasumber telah dengan sengaja mencari informasi ke kantor PLN unit dan membuat laporan pengaduan di tingkat desa dan kecamatan.

Selain melakukan usaha membuat laporan pengaduan, sebagian besar narasumber juga melakukan usaha lebih lanjut untuk mendapatkan informasi yang lebih mendalam dan terperinci mengenai aturan yang berlaku. Beberapa media dimanfaatkan narasumber untuk memperoleh informasi yang lebih jelas. Media yang dimanfaatkan oleh para narasumber untuk menambah informasi seputar aturan yang berlaku antara lain poster, iklan di televisi, petugas catat meter PLN, petugas pelayanan pelanggan di kantor PLN, pegawai tingkat kelurahan/desa, dan pegawai tingkat kecamatan.

Namun demikian, terdapat pula narasumber yang tidak terlalu mempermasalahkan adanya kenaikan tarif yakni Narasumber 2. Konsumen tersebut pada dasarnya juga mengetahui dan tidak mempermasalahkan adanya aturan di tarif daya 900 VA yang lebih murah. Narasumber 2 juga tidak melakukan usaha khusus untuk pencarian informasi yang lebih mendalam dan rinci mengenai aturan yang berlaku. Pemahaman atas aturan daya 900 VA diperoleh atas informasi yang diterima narasumber tanpa ada usaha khusus lebih lanjut. Secara keseluruhan pelanggan tersebut menerima pemberlakuan aturan dan mempercayakan kesesuaian data oleh para pemangku kepentingan.

Berlanjut ke tahap Perceptual Organization, para narasumber yang telah memilih beragam stimuli dari lingkungan mencoba mengorganisasikannya kedalam kelompok-kelompok namun tetap mengangapnya sebagai suatu kesatuan utuh. Beragam stimuli yang telah dipilih akhirnya disederhanakan oleh narasumber dalam membentuk pola pemikiran. Pada tahap ini peneliti ingin mengetahui pola pengorganisasian dengan sudut pandang kelebihan dan kekurangan yang dirasakan narasumber atas aturan yang diberlakukan. 
Hanya sedikit narasumber yang mengutarakan kelebihan dari aturan yang diberlakukan daya 900 VA. Dari keenam narasumber diketahui bahwa hanya Narasumber 5 yang telah menyatakan secara lugas kelebihan pemberlakukan aturan tersebut. Hal ini dikarenakan Narasumber 5 mendapatkan manfaat dan keuntungan atas pemberlakukan aturan tersebut yakni ditetapkannya tarif R1-900 pada sambungan listrik di rumahnya. Sedangkan para narasumber lain tidak terlalu memberikan jawaban jelas atas kelebihan aturan tersebut.

Banyak kekurangan atas penerapan aturan yang telah disampaikan oleh narasumber sebagai akibat dari pengenaaan tarif yang lebih tinggi. Ketidaksesuaian tarif dengan kondisi ekonomi, kesalahan pendataan, dan kurangnya sosialisasi menjadi hal yang dipermasalahkan oleh beberapa narasumber dan dianggap sebagai bagian dari kekurangan implementasi aturan. Banyak jawaban yang berfokus pada sisi kekurangan aturan telah disampaikan oleh narasumber bergantung pada permasalahan yang dihadapi oleh masing-masing narasumber.

Pada tahap Perceptual Interpretation terjadi proses yang lebih personal. Beragam stimuli yang telah dipilih dan diorganisasikan maka dilanjut dengan usaha interpretasi oleh setiap individu bergantung pada pengalaman yang telah dimiliki sebelumya dikaitkan dengan motivasi dan keinginan dari setiap narasumber.

Hasil dari interpretasi setiap individu dalam pembentukan persepsi tentu tidak akan selalu sesuai dengan kenyataan yang tepat. Sebagaimana disampaikan Schiffman dan Kanuk (2007) bahwa seberapa dekat interpretasi dengan kenyataan sesungguhnya bergantung pada kejelasan stimulus, pengalaman masa lalu dari pemersepsi, dan motif-kepentingan individu saat dilakukan proses pembentukan persepsi.

Fokus jawaban pelanggan semakin beragam karena setiap narasumber memiliki dasar pengalaman dan keinginan yang berbeda-beda yang berhubungan dengan pemberlakukan aturan sambungan listrik daya 900 VA. Pada pertanyaan yang sama setiap narasumber memberikan sudut pandangnya sendiri.

Sebagian besar narasumber menyatakan bahwa pemerintah dan PLN masih dirasakan kurang dalam melaksanakan kegiatan sosialisasi aturan. Usaha mencari informasi lebih lanjut dan melakukan pengaduan sesuai prosedur juga telah dilakukan oleh Narasumber 1, 2, 4, dan 6, namun demikian masih memunculkan kesimpulan bahwa kegiatan sosialisasi dirasa kurang. Pernyataan yang sama juga disampaikan oleh Narasumber 5 meskipun telah mendapatkan manfaat atas penerapan tarif yang lebih rendah yakni R1-900 pada sambungan listrik di rumahnya. Hanya Narasumber 3 yang menyatakan netral dengan penilaian atas proses sosialiasi karena secara pribadi telah menerima pemberlakuan aturan tersebut dan tidak mempermasalahkannya.

Dalam hal penerapan aturan, kesesuaian tarif di sambungan listrik rumah narasumber, dan usaha-usaha tindak lanjut yang ditanggapi beragam oleh serangkaian Narasumber. Dari jawaban 6 narasumber penelitian yang telah disampaikan, masing-masing memiliki karakteristik yang berbeda. Hal ini menunjukkan bahwa proses persepsi di masing-masing 
individu berlangsung cukup personal karena dikaitkan dengan apa yang telah ada di benak pelanggan sebelumnya. Hasil interpretasi oleh seorang individu bisa saja sesuai dengan aturan yang sebenarnya, namun juga bisa jauh berbeda. Kondisi itu semua merupakan fakta nyata yang ada para narasumber selaku konsumen listrik PLN.

Ada 1 narasumber yang masih mengkaitkan aturan di daya 900 VA dengan program lain yang telah diterima sebelumnya. Konsumen merasa diuntungkan dari program sebelumnya atas biaya yang murah untuk naik daya namun terbebani dengan tarif yang lebih tinggi di tarif R1900M. Meskipun sudah ada usaha tindak lanjut dari narasumber untuk mencari informasi dan membuat pengaduan resmi, pada akhirnya tarif yang diberlakukan masih tetap R1900M. Namun demikian Narasumber tidak terlalu berpikir negatif mengenai pemberlakukan aturan di daya 900 VA dan berusaha menerimanya.

Fokus dari kebanyakan narasumber atas kekurangan penerapan aturan lebih pada kekecewaaan yang mereka peroleh selaku pelanggan PLN. Bahkan beberapa narasumber menyatakan merasa tidak ada kelebihan atas penerapan aturan tersebut karena merasa tidak mendapatkan manfaat atas tarif yang diberlakukan di sambungan listrik rumahnya.

Hasil dari usaha pencarian informasi secara khusus oleh beberapa narasumber telah mengemukakan kekecewaan akibat proses konfirmasi yang terkesan berbelit dan dirasakan kurang memberikan kepastian. Kekecewaan juga muncul sebagai hasil dari usaha melakukan pengaduan yang telah sesuai prosedur tetapi hasilnya masih memposisikan penerapan tarif yang lebih tinggi (R1-900M) bagi para narasumber. Apalagi 2 narasumber menyatakan bahwa basis data bagi mereka untuk mendapatkan tarif yang lebih ringan (R1-900) justru telah digunakan oleh pelanggan lain (pada narasumber 1 dan 4).

\section{SIMPULAN}

Proses persepsi para konsumen PLN atas penerapan aturan penyesuaian subsidi bertahap dan penerapan tarif ganda yang dianalisis berdasarkan 3 tahapan yaitu Selection, Organization, dan Interpretation. Dimulai dengan tahapan selection dimana para narasumber melakukan pemilihan atas beragam stimuli atau rangsangan yang diterima. Rangsangan yang paling kuat dan mempengaruhi banyak narasumber adalah pada nilai tagihan atau token yang dinilai semakin mahal. Disamping itu pula juga banyak sumber stimuli lain yang menambah pemahaman narasumber akan aturan yang diberlakukan.

Pembentukan persepsi pada individu dilanjutkan pada tahapan organization dimana narasumber mencoba mengolah berbagai stimuli yang diterima untuk lebih memudahkan pemahaman atas adanya aturan yang diberlakukan. Dari hasil wawancara pada tahapan organization menunjukkan sebagian Narasumber lebih memberi fokus pada kekurangan atas penerapan aturan. Kondisi tersebut muncul karena berkaitan praktis dengan manfaat yang diperoleh sebagai pelanggan akibat penerapan tarif yang lebih tinggi (R1-900M) di sambungan listrik rumahnya. Hanya sedikit dari para narasumber yang mampu menjelaskan kelebihan dari penerapan aturan tersebut. 
Pada tahapan interpretation para narasumber memiliki pandangan yang beragam atas adanya penerapan aturan tersebut. Hal ini karena masing-masing narasumber akan membandingkan stimuli atau rangsangan yang diterima dengan motif dan ketertarikan yang telah mereka miliki sebelumnya. Setiap narasumber memiliki dasar sudut pandang yang lebih personal meskipun untuk menilai penerapan aturan yang sama. Interpretasi yang ada para Narasumber berkaitan erat dengan manfaat praktis yang diterima oleh individu. Oleh karena itu pembuatan interpretasi di benak narasumber atas penerapan aturan tersebut cenderung berkaitan erat dengan tarif yang ditetapkan pada sambungan listrik di rumah masing-masing. Selain itu hasil interpretasi pada para pelanggan juga memberikan penekanan perhatian pada proses sosialisasi oleh PLN dan pemerintah yang dirasakan masih kurang. Banyak keluhan yang telah muncul dari para narasumber berkaitan dengan proses sosialisasi tersebut.

Terdapat usaha aktif dari sebagian besar narasumber untuk mencari informasi lebih lanjut mengenai aturan yang diterapkan pada sambungan listrik daya 900 VA di rumah masingmasing. Para narasumber dengan sengaja telah memanfaatkan beberapa media untuk mencari informasi terkait rincian aturan yang berkaitan langsung dengan pembayaran listrik mereka sebagai kebutuhan dasar. Para narasumber lebih berfokus pada usaha pencarian informasi yang hanya berkaitan langsung dengan pemenuhan kebutuhan praktis mereka.

Merupakan kesimpulan dari penelitian yang dilakukan, memberikan pernyataan bahwa apa yang tertera dalam bagian "Pendahuluan" memiliki hubungan dengan "Hasil dan Pembahasan". Selain itu, dapat juga ditambahkan prospek pengembangan hasil penelitian dan prospek penerapan studi lanjut di masa yang akan datang (berdasarkan temuan dan diskusi).

Setelah dilakukannya penelitian ini, maka peneliti memiliki harapan adanya penelitian lebih lanjut yang memiliki kaitan dengan pembahasan yang sama. Lingkup masalah yang bisa diteliti lebih lanjut masih sangat luas, baik itu menggunakan metode yang sama ataupun berbeda serta jika didukung pula dengan dasar teori yang masih relevan.

Saran praktis atas adanya penerapan aturan penyesuaian subsidi bertahap dan penerapan tarif ganda daya 900 VA adalah PLN maupun Pemerintah perlu menjalankan proses sosialisasi yang lebih baik kepada para pelanggan sehingga tidak terjadi kebingungan di tingkat pengguna akhir. Kemudian ketepatan data menjadi penting karena berpengaruh terhadap nilai biaya listrik yang dibayarkan oleh pelanggan. Dari penelitian diketahui bahwa beberapa narasumber merasa memiliki hak untuk mendapatkan tarif yang lebih murah namun dasar datanya telah digunakan untuk meter $\mathrm{kWh}$ milik pelanggan lain. 


\section{DAFTAR PUSTAKA}

Dirjen Ketenagalistrikan, et al. (2016). Petunjuk Teknis Pelaksanaan Kebijakan Subsidi Listrik Tepat Sasaran. Dirjen Gatrik : Jakarta

Dirjen Ketenagalistrikan, et al. (2016). Tanya Jawab Kebijakan Subsidi Tepat Sasaran. Dirjen Gatrik : Jakarta

Hidayat, D., N. (2007). Pengantar Komunikasi Massa. Jakarta: Rajagrafindo Perkasa

Kotler, P., Keller, K. L. 2012. Marketing Management. $14^{\text {th }}$ Edition. New Jersey: Prentice Hall Moleong, L. J. (2016). Metodologi Penelitian Kualitatif. Bandung: Rosda

Mulyana, D. (2012). Ilmu Komunikasi: Suatu Pengantar. Bandung: Remaja Rosdakarya

Mulyana, D., Solatun. (2008). Metode Penelitian Komunikasi - contoh-contoh Penelitian Kualitatif dengan Pendekatan Praktis. Bandung: Remaja Rosdakarya

Profil perusahaan (n.d.) diperoleh pada januari 18, 2018 dari www.pln.co.id/tentangkami/profil-perusahaan

Schiffman, L. G., Kanuk, L. L. (2007). Consumer Behavior ( $9^{\text {th }}$ Edition, Global Edition). New Jersey: Pearson Education 